\title{
ANALISIS POLA ASUH ORANG TUA TERHADAP GAYA BELAJAR SISWA DI SEKOLAH MENENGAH ATAS KHARISMAWITA JAKARTA SELATAN
}

\author{
Imam Sibawaih $^{1}$ dan Anita Tri Rahayu ${ }^{2}$ \\ ${ }^{1}$ Dosen Program Studi Pendidikan Ekonomi Universitas Indraprasta PGRI \\ ${ }^{2}$ Dosen Program Studi Bimbingan dan Konseling Universitas Indraprasta PGRI \\ Email: imamsiba@gmail.com
}

\begin{abstract}
Abstrak
Tujuan dari penelitian ini adalah untuk mengetahui pengaruh pola asuh orang tua terhadap gaya belajar siswa di SMA kharismawita Jakarta Selatan. Metode yang digunakan penulis dalam penelitian ini adalah metode survey dengan 2 variabel, yaitu variabel $\mathrm{x}$ dan variabel $\mathrm{y}$, dengan menganalisis tentang pola asuh orang tua yang berdampak pada gaya belajar siswa di sekolah. Sampel dalam penelitian ini dilaksanakan secara sampling random (acak). Sampel dalam penelitian ini sebanyak 30 siswa yaitu jumlah sampel ideal pada setiap populasi. Instrumen yang digunakan adalah lembar angket tertutup. Perhitungan statistik menggunakan uji hipotesis yaitu uji t. Nilai koefisien determinasi (KD) sebesar 0,64\%, berarti kontribusi hubungan variable X (pola asuh orang tua) hanya sebesar 0,64\% saja, sisanya sebesar 99,36\% dipengaruhi oleh faktor lain Hasil uji hipotesis dengan t tabel pada df $=30-2=$ 28 dengan taraf signifikasi 10\% didapat hasil 1,313. Sehingga hipotesis alternative (Ha) ditolak yaitu tidak terdapat hubungan yang signifikan antara variable $\mathrm{X}$ (pola asuh orang tua) dengan variable Y (gaya belajar siswa). Adapun alasan ditolaknya Ha dan diterimanya Ho adalah karakteristik siswa di SMA kharismawita yang berusia remaja dimana pada usia ini anak sudah dapat menentukan pola belajar sesuai dengan karakteristik pribadinya tanpa pengaruh dari lingkungan di luar dirinya.
\end{abstract}

Kata Kunci : Pola asuh orang tua dan gaya belajar siswa.

\section{PENDAHULUAN}

Orang tua merupakan salah satu faktor eksternal yang dapat mempengaruhi prestasi belajar siswa. Pola asuh orang tua sangat berpengaruh pada prestasi siswa. Selain pola asuh orang tua, keberhasilan seorang anak dalam mencapai prestasi belajarnya sangat dipengaruhi oleh gaya belajar sebagai faktor internalnya. Salah satu keberhasilan seorang anak dalam pendidikan dapat ditunjukkan dengan prestasi belajarnya di bidang akademik, namun pada kenyataannya yang telah terjadi saat ini adalah semakin tingginya tuntutan siswa untuk meningkatkan prestasi akademik, sementara proses belajar atau daya belajar yang dimiliki siswa masih dalam tahap biasa saja.

Penerapan pola asuh orang tua dapat mempengaruhi kebiasaan belajar siswa baik di rumah maupun di sekolah. Kebiasaan belajar inilah yang menyebabkan sebuah pola yang disebut sebagai gaya belajar. Dunn dan Dunn dalam bukunya psikologi pendidikan (Sugihartono, 2007: 53) menjelaskan bahwa gaya belajar merupakan 
kumpulan karakteristik pribadi yang membuat suatu pembelajaran efektif untuk beberapa orang dan tidak efektif untuk orang lain. Berarti gaya belajar merupakan cara anak belajar yang paling disukainya.

Setiap orang memiliki gaya belajar masing-masing. Pengenalan gaya belajar sangat penting. Bagi guru dengan mengetahui gaya belajar tiap siswa maka guru dapat menerapkan teknik dan strategi yang tepat, baik dalam pembelajaran maupun pengembangan diri. Seorang siswa juga harus mengetahui jenis gaya belajarnya. Dengan demikian ia telah memiliki kemampuan mengenal diri yang lebih baik dan mengetahui kebutuhannya. Pengenalan gaya belajar akan memberikan pelayanan yang tepat terhadap apa dan bagaimana sebaiknya disediakan dan dilakukan agar pembelajaran dapat berlangsung optimal.

Menurut Rita Dunn (Sugihartono, 2007) pelopor di bidang gaya belajar yang lain telah menemukan banyak variable yang mempengaruhi gaya belajar siswa, diantaranya: fisik, emosional, sosiologis dan lingkungan. Salah satunya adalah lingkungan keluarga. Seseorang yang belajar akan menerima pengaruh dari keluarga berupa cara orang tua mendidik, relasi antar anggota keluarga, suasana rumah tangga dan keadaan ekonomi keluarga.

Pola asuh menurut Casmini dalam Palupi (2007:3) adalah bagaimana orang tua memperlakukan anak, mendidik, membimbing dan mendisiplinkan serta melindungi anak dalam mencapai proses kedewasaan hingga keadaan upaya pembentukan normanorma yang diharapkan oleh masyarakat pada umumnya. Pola asuh sebagai bentuk interaksi antara orang tua dan anak perlu diketahui dan dikaji mendalam dalam upaya peningkatan prestasi belajar siswa.

Kondisi saat ini, sebagian besar kedua orang tua bekerja sehingga perhatian terhadap anak tentu tidaklah optimal. Hal inilah yang mempengaruhi gaya belajar siswa dan perhatian siswa terhadap prestasi belajarnya di sekolah. Guru sebagai pendidik disekolah memerlukan bantuan penuh dari orang tua sebagai mitra belajar anak dirumah. Untuk itulah penelitian ini dilakukan agar sekolah dalam hal ini guru dapat mengetahui peran orang tua melalui pola asuhnya dikeluarga dan gaya belajar yang dimiliki siswanya. Sehingga proses belajar mengajar dapat berlangsung optimal. 


\section{TINJAUAN PUSTAKA}

\section{Gaya Belajar}

Para ahli memberikan pengertian beberapa pengertian gaya belajar. Pada dasarnya kemampuan seseorang untuk memahami sudah pasti berbeda tingkatannya. Ada yang cepat, sedang dan adapula yang sangat lambat. Oleh karena itu, siswa seringkali harus menempuh cara yang berbeda untuk bisa memamahi informasi dan pelajaran yang sama. Gaya belajar merupakan cara belajar yang khas bagi siswa. (Winkel, 2009)

Apapun cara yang dipilih, perbedaan gaya belajar itu menunjukkan cara tercepat dan ternaik bagi setiap individu untuk bias menyerap sebuah informasi dari luar dirinya. Jika seseorang bisa memahami bagaimana perbedaan gaya belajar setiap orang, maka dapat memandu seseorang untuk mendapatkan gaya belajar yang tepat dan memberikan hasil yang maksimal bagi dirinya.

Menurut Nasution (2011) gaya belajar atau learning style siswa yaitu cara bereaksi dan menggunakan perangsang-perangsang yang diterima dalam proses belajar. Menurut Deporter dan Hernacki (2011) gaya belajar merupakan suatu kombinasi dari bagaimana seseorang menyerap dan kemudian mengatur serta mengolah informasi. Gaya belajar bukan hanya berupa aspek ketika menghadapi informasi, melihat, mendengar, menulis dan berkata. Tetapi juga aspek pemrosesan informasi sekunsial, analitik, global atau otak kiri dan otak kanan, aspek lain adalah ketika merespon sesuatu atas lingkungan belajar (belajar diserap secara abstrak dan konkret). Gaya belajar juga merupakan kecenderungan siswa untuk mengadaptasi strategi tertentu dalam belajarnya sebagai bentuk tanggung jawabnya untuk mendapatkan satu pendekatan belajar yang sesuai dengan tuntutan belajar di kelas/ sekolah maupun tuntutan dari mata pelajaran (Slameto, 2003).

Dari penjelasan para ahli di atas, dapat disimpulkan bahwa gaya belajar adalah cara yang cenderung dipilih siswa untuk bereaksi dan menggunakan perangsangperangsang dalam menyerap kemudian mengatur serta mengolah informasi pada proses belajar.

\section{Macam-Macam Gaya Mengajar}

Fleming dan Mills (1992) dalam Slameto (2003) mengajukan kategori gaya belajar (Learning Style) VARK (Visual, Auditory, Read-write, Kinestetic) tersebut sebagai berikut : 


\section{Visual (V)}

Kecenderungan ini mencakup menggambarkan informasi dalam bentuk peta, diagram, garfik, flow chart dan symbol visual seperti panah, lingkaran, hirarki dan materi lain yang digunakan instruktur untuk mempresentasikan hal-hal yang dapat disampaikan dalam kata-kata. Hal ini mencakup juga desain, pola, bentuk dan format lain yang digunkan untuk menandai dan menyampaikan informasi.

a). Beberapa karakteristik Visual Learner adalah: Senantiasa melihat bibir guru yang sedang mengajar; Menyukai instruksi tertulis, foto dan ilustras untuk dilihat; Saat petunjuk untuk melakukan sesuatu diberikan biasanya kan melihat teman-teman lainnya baru dia sendiri bertindak; Cenderung menggunakan gerakan tubuh untuk mengekspresikan atau mengganti sebuah kata saat mengungkapkan sesuatu; Kurang menyukai berbicara di depan kelompok dan kurang menyukai untuk mendengarkan orang lain; Biasanya tidak dapat mengingat informasi yang diberikan secara lisan; Menyukai diagram, kalender maupun grafik time-line untuk mengingat bagian peristiwa; Selalu mengamati seluruh elemen fisik dari lingkungan belajar; Lebih menyukai peragaan daripada penjelasan lisan; Biasanya tipe ini dapat duduk tenang di tengah situasi yang ribut atau ramai tanpa merasa terganggu; Mengorganisir materi belajarnya dengan hati-hati; Berusaha mengingat dan memahami menggunakan diagram, table dan peta; serta Mempelajari materi dengan membaca catatan dan membuat ringkasan.

b). Media atau bahan yang cocok, meliputi: Guru yang menggunakan bahasa tubuh atau gambar dalam keadaan menerangkan; Media gambar, video, poster dan sebagainya; Buku yang banyak mencantumkan diagram atau gambar; Flow chart; Grafik; Menandai bagian-bagian yang penting dari bahan ajar dengan menggunakan warna yang berbeda; serta Symbol-simbol visual.

c). Strategi belajarnya melalui cara mengganti kata-kata dengan symbol atau gambar.

2). Aural atau Auditory Learning (A)

Modalitas ini menggambarkan preferensi terhadap informasi yang didengar atau diucapkan. Siswa dengan modalitas ini belajar secara maksimal dari ceramah, 
tutorial, tape diskusi kelompok, bicara dan membicarakan materi. Hal ini mencangkup berbicara dengan suara keras atau bicara kepada diri sendiri.

a). Beberapa karakteristik Auditory Learner antara lain: Mampu mengingat dengan baik apa yang mereka katakana maupun yang orang lain sampaikan; Mengingat dengan baik dengan jalan selalu mengucapkan dengan nada keras dan mengulang-ulang kalimat; Sangat menyukai diskusi kelompok; Menyukai diskusi yang lebih lama terutama untuk hal-hal yang kurang mereka pahami; Mampu menginngat dengan baik materi yang didiskusikan dalam kelompok atau kelas; Mengenal banyak sekali lagu atau iklan TV dan bahkan dapat menirukannya secara tepat dan komplit; Suka berbicara; Kurang suka tugas membaca (dan pada umumnya bukanlah pembaca yang baik); Kurang dapat mengingat dengan baik apa yang baru saja dibacanya; Kurang dalam mengerjakan tugas mengarang atau menulis; Kurang memperhatikan hal-hal baru dalam lingkungan sekitarnya seperti : hadirnya anak baru, adanya papan pengumuman yang baru dsb; Sukar bekerja dengan tenang tanpa menimbulkan suara; serta Mudah terganggu konsentrasi karena suara dan juga susah berkonsentrasi bila tidak ada suara sama sekali.

b). Media atau bahan yang cocok meliputi: Menghadiri kelas; Diskusi; Membahas suatu topic bersama dengan teman; Membahas suatu topic bersama dengan guru; Menjelaskan ide-ide baru kepada orang lain; Menggunakan perekam; Mengingat cerita, contoh atau lelucon yang menarik; Menjelaskan bahan yang didapat secara visual (gambar, power point dsb)

c). Strategi belajar meliputi: Catatan yang dibuat mungkin sangat tidak memadai. Tambahkan informasi yang didapat dengan cara berbicara dengan orang lain dan mengumpulkan catatan dari buku; Rekam ringkasan dari catatan yang dibuat dan dengarkan rekaman tersebut; Minta orang lain untuk mendengar pemahaman yang diterima mengenai suatu topic; serta Baca buku atau catatan dengan keras.

3). Read-Write

a). Media/bahan yang cocok adalah Kamus; Handout; Buku teks; Catatan; Daftar; Essay; dan Membaca buku manual. 
b). Strategi belajarnya meliputi: Tuliskan kata-kata secara berulang-ulang; Baca catatan Anda (dengan sunyi) secara berkali-kali; Tulis kembali ide atau informasi dengan kalimat yang berbeda; dan Terjemahkan semua diagram, gambar, dan sebagainya ke dalam kata-kata.

\section{4). Kinestetic atau Tactile Learner (K)}

Berdasarkan definisi, modalitas ini mengarah pada pengalaman dan latihan (simulasi atau nyata, meskipun pengalaman tersebut melibatkan modalitas lain. Hal ini mencakup demonstrasi, simulasi, video dan film dari pelajaran yang sesuai aslinya, sama halnya dengan studi kasus, latihan dan aplikasi.

a). Beberapa karakteristiknya adalah: Suka menyentuh segala sesuatu yang dijumpainya; Sulit untuk berdiam diri; Suka mengerjakan segala sesuatu dengan menggunakan tangan; Biasanya memiliki koordinasi tubuh yang baik; Suka menggunakan objek yang nyata sebagai alat bantu belajar; Mempelajari hal-hal yang abstrak (symbol matematika, peta dsb); Mengingat secara baik bila secara fisik terlibat aktif dalam proses pembelajaran; Menikmati kesempatan untuk menyusun atau menangani secara fisik materi pembelajaran; Sering berusaha membuat catatan hanya untuk menyibukkan diri tanpa memanfaatkan hasil catatan tersebut; Menyukai penggunaan computer; Mengungkapkan minat dan ketertarikan terhadap sesuatu secara fisik dengan bekerja secara antusias; Sulit apabila diminta untik berdiam diri atau berada disuatu tempat untuk beberapa lama tanpa aktifitas fisik; serta Sering bermain-main dengan benda disekitarnya sambil mendengarkan atau mengerjakan sesuatu.

b). Media/ bahan yang cocok yaitu: Menggunakan seluruh panca indera (penglihatan, sentuhan, pengecap, penciuman, pendengaran); Laboratorium; Kunjungan lapangan; Pembicara yang memberikan contoh kehidupan nyata; Pengaplikasian; Pameran, sampel, fotografi; serta Koleksi berbagai macam tumbuhan, serangga dan sebagainya.

c). Strategi belajarnya meliputi: Mengingat kejadian nyata yang terjadi; Masukan berbagai macam contoh untuk memudahkan dalam mengingat konsep; Gunakan benda-benda untuk mengilustrasikan ide; Kembali ke laoratorium atau tempat belajar dapat melakukan eksperimen; serta 
Mengingat kembali mengenai eksperimen, kunjungan lapangan dan sebagainya.

Dalam gaya belajar dikenal juga istilah multi modalitas dan tunggal modalitas. Tunggal modalitas yaitu satu tipe gaya belajar seperti visual learner/ auditory learner/ read write ataupun kinesthetic learner. Sedangkan pada multi modalitas akan mempunyai lebih dari satu tipe gaya belajar. Setiap orang berpotensial memiliki tipe belajar multimodalitas tergantung bagaimana semua indera yang seseorang tersebut miliki untuk dilatih.

Pada dasarnya dengan multimodalitas seseorang dapat menerima proses belajar dalam kondisi dengan cara beradaptasi terhadap model pembelajarannya.

Baykan dan Nacar (2007) yang membandingkan prestasi belajar siswa yang gaya belajarnya tunggalmodalitas dan multimodalitas. Hasilnya menunjukkan bahwa tidak ada perbedaan hasil belajar yang signifikan.

\section{Pola Asuh}

\section{a. Pengertian Pola Asuh}

Pola asuh terdiri dari dua kata yaitu pola dan asuh. Menurut Kamus Besar Bahasa Indonesia, “pola berarti corak, model, sistem, cara kerja, bentuk (struktur) yang tetap”. (Depdikbud, 2007:884). Sedangkan kata “asuh” dapat berarti menjaga (merawat dan mendidik) anak kecil, membimbing (membantu ; melatih dan sebagainya), dan memimpin (mengepalai dan menyelenggarakan) satu badan atau lembaga”. (KBBI, 2007:73).

Jadi pola asuh orang tua adalah suatu keseluruhan interaksi antara orang tua dengan anak, di mana orang tua bermaksud menstimulasi anaknya dengan mengubah tingkah laku, pengetahuan serta nilai-nilai yang dianggap paling tepat oleh orang tua, agar anak dapat mandiri, tumbuh dan berkembang secara sehat dan optimal.

Pengasuhan (parenting) memerlukan sejumlah kemampuan interpersonal dan mempunyai tuntutan emosional yang besar, namun sangat sedikit pendidikan formal menganai tugas ini. Kebanyakan orang tua mempelajari praktik pengasuhan dari orng tua mereka sendiri. Sebagian praktik tersebut mereka terima, namun sebagai lagi mereka tinggalkan. Suami dan istri mungkin saja membawa pandangan 
yang berbeda mengenai pengasuhan ke dalam pernikahan.(John W Santrock, 2007: 163)

Pola asuh orang tua dapat membantu anak untuk mengembangkan disiplin diri ini adalah upaya orang tua yang diaktualisasikan terhadap penataan : lingkungan fisik, lingkungan sosial internal dan eksternal, pendidikan internal dan eksternal, dialog dengan anak-anak, suasana psikologis, sosiobudaya, perilaku yang ditampilkan pada saat terjadinya pertemuan dengan anak-anak, kontrol terhadap perilaku anak-anak dan menentukan nilai-nilai moral sebagai dasar berprilaku dan yang diupayakan kepada anak-anak. Pola asuh orang tua dengan anak berdisiplin diri dimasukkan sebagai upaya orang tua dalam "meletakkan“ dasar-dasar disiplin diri kepada anak dan membantu mengembangkannya sehingga anak memiliki disiplin diri. (Moh Shochib, 2010: 15)

b. Macam-macam Pola Asuh

Menurut Hurlock (2002:204) ada beberapa sikap orang tua yang khas dalam mengasuh anaknya, antara lain:

1) Melindungi secara berlebihan. Perlindungan orang tua yang berlebihan mencakup pengasuhan dan pengendalian anak yang berlebihan.

2) Permisivitas. Permisivitas terlihat pada orang tua yang membiarkan anak berbuat sesuka hati dengan sedikit pengendalian.

3) Memanjakan. Permisivitas yang berlebih-memanjakan membuat anak egois, menuntut dan sering tiranik.

4) Penolakan. Penolakan dapat dinyatakan dengan mengabaikan kesejahteraan anak atau dengan menuntut terlalu banyak dari anak dan sikap bermusuhan yang terbuka.

5) Penerimaan. Penerimaan orang tua ditandai oleh perhatian besar dan kasih sayang pada anak, orang tua yang menerima, memperhatikan perkembangan kemampuan anak dan memperhitungkan minat anak.

6) Dominasi. Anak yang didominasi oleh salah satu atau kedua orang tua bersifat jujur, sopan dan berhati-hati tetapi cenderung malu, patuh dan mudah dipengaruhi orang lain, mengalah dan sangat sensitif.

7) Tunduk pada anak. Orang tua yang tunduk pada anaknya membiarkan anak mendominasi mereka dan rumah mereka. 
8) Favoritisme. Meskipun mereka berkata bahwa mereka mencintai semua anak dengan sama rata, kebanyakan orang tua mempunyai favorit. Hal ini membuat mereka lebih menuruti dan mencintai anak favoritnya dari pada anak lain dalam keluarga.

9) Ambisi orang tua. Hampir semua orang tua mempunyai ambisi bagi anak mereka seringkali sangat tinggi sehingga tidak realistis. Ambisi ini sering dipengaruhi oleh ambisi orang tua yang tidak tercapai dan hasrat orang tua supaya anak mereka naik di tangga status sosial.

Dalam mengasuh anak orang tua cenderung menggunakan pola asuh tertentu. Menurut Baumrind, Maccoby dan Martin dalam Papalia (2008) terdapat 3 macam pola asuh orang tua yaitu demokratis, otoriter dan permisif.

1) Demokratis

Pola asuh demokratis adalah pola asuh yang memprioritaskan kepentingan anak, akan tetapi tidak ragu dalam mengendalikan mereka. Orang tua dengan perilaku ini bersikap rasional, selalu mendasari tindakannya pada rasio atau pemikiranpemikiran. Orang tua tipe ini juga bersikap realistis terhadap kemampuan anak, tidak berharap yang berlebihan yang melampaui kemampuan anak. Misalnya ketika orang tua menetapkan untuk menutup pintu kamar mandi ketika sedang mandi dengan diberi penjelasan, mengetuk pintu ketika masuk kamar orang tua, memberikan penjelasan perbedaan laki-laki dan perempuan, berdiskusi tentang hal yang tidak boleh dilakukan anak misalnya tidak boleh keluar dari kamar mandi dengan telanjang, sehingga orang tua yang demokratis akan berkompromi dengan anak. (Debri, 2008).

2) Otoriter-Pengertian Pola Asuh Menurut Para Ahli Pola asuh ini sebaliknya cenderung menetapkan standar yang mutlak harus dituruti, biasanya dibarengi dengan ancaman-ancaman mislalnya, kalau tidak mau makan, maka tidak akan diajak bicara. Orang tua tipe ini cenderung memaksa, memerintah dan menghukum. Apabila anak tidak mau melakukan apa yang dikatakan oleh orang tua, maka orang tua tipe ini tidak segan menghukum anak. Misalnya anaknya harus menutup pintu kamar mandi ketika mandi tanpa penjelasan anak laki-laki tidak boleh bermain dengan anak perempuan, melarang anak bertanya kenapa dia lahir, anak dilarang bertanya tentang lawan jenisnya. 
Dalam hal ini tidak mengenal kompromi. Anak suka atau tidak suka, mau atau tidak mau harus memenuhi target yang ditetapkan orang tua.

3) Permisif

Pola asuh ini memberikan kesempatan pada anaknya untuk melakukan sesuatu tanpa pengawasan yang cukup darinya. Misalnya anak yang masuk kamar orang tua tanpa mengetuk pintu dibiarkan, telanjang dari kamar mandi dibiarkan begitu saja tanpa ditegur, membiarkan anak melihat gambar yang tidak layak untuk anak kecil, dengan pertimbangan anak masih kecil.

c. Faktor Utama yang Mempengaruhi Pola Asuh

1) Budaya

Orang tua mempertahankan konsep tradisional mengenai peran orang tua merasa bahwa orang tua mereka berhasil mendidik mereka dengan baik, maka mereka menggunakan teknik yang serupa dalam mendidik anak asuh mereka.

2) Pendidikan Orang Tua

Orang tua yang memiliki pengetahuan lebih banyak dalam mengasuh anak, maka akan mengerti kebutuhan anak.

3) Status Sosial Ekonomi

Orang tua dari kelas menengah rendah cenderung lebih keras/lebih permessif dalam mengasuh anak (Hurlock, 2002).

\section{Pengaruh Pola Asuh Terhadap Gaya Belajar Siswa}

Pola asuh yang efektif itu bisa dilihat dari hasilnya anak jadi mampu memahami aturan-aturan di masyarakat, syarat paling utama pola asuh yang efektif adalah landasan cinta dan kasih sayang.

Penerapan pola asuh orang tua dapat mempengaruhi kebiasaan belajar siswa baik di rumah maupun di sekolah. Kebiasaan belajar inilah yang menyebabkan sebuah pola yang disebut sebagai gaya belajar. Orang tua merupakan salah satu faktor eksternal yang dapat mempengaruhi prestasi belajar siswa. Pola asuh orang tua sangat berpengaruh pada prestasi siswa. Selain pola asuh orang tua, keberhasilan seorang anak dalam mencapai prestasi belajarnya sangat dipengaruhi oleh gaya belajar sebagai faktor internalnya. 


\section{METODE}

Dalam penelitian ini bertujuan untuk menganalisis dan mengetahui pengaruh pola asuh orang tua terhadap gaya belajar siswa di sekolah. Metode penelitian yang digunakan oleh penulis untuk mengetahui regresi antara dua variable yaitu pola asuh sebagai variabel bebas (x) dan gaya belajar sebagai variabel terikat (y) adalah metode survey dengan pendekatan regresional.

Sampel dalam penelitian ini dilaksanakan secara sampling random (acak) artinya setiap unsur populasi mempunyai kesempatan yang sama untuk terambil sebagai unsur dalam sampel. Sampel dalam penelitian ini sebanyak 30 siswa yaitu jumlah sampel ideal pada setiap populasi.

Instrumen yang digunakan adalah lembar angket tertutup. Angket tertutup adalah angket yang telah dilengakapi dengan alternative jawaban dan responden tinggal memilihnya. Pengukuran angket menggunakan skala bertingkat. Jawaban dari setiap item instrument yang menggunakan skala bertingkat berupa kata-kata, yaitu: Selalu (S), Sering (SR), Jarang (JR), dan Tidak Pernah (TP).

Angket disusun berdasarkan kisi-kisi instrumen dan variabel-variabel yang digunakan. Tabel berikut adalah kisi-kisi instrumen dari masing-masing variabel:

Tabel Kisi-kisi Instrumen Pola Asuh Orang Tua

\begin{tabular}{|c|c|c|c|}
\hline Variabel & Indikator & Nomor Butir & Jumlah \\
\hline $\begin{array}{l}\text { Pola Asuh } \\
\text { Orang Tua }\end{array}$ & 1. Pola Asuh Demokratis & $1,2,3,4,5,6,7,8$ & 8 \\
\hline & $\begin{array}{l}\text { 2. Pola Asuh Otoriter } \\
\text { 3. Pola Asuh Permisive }\end{array}$ & $\begin{array}{c}9,10,11,12,13,14,15,16 \\
17,18,19,20.21,22,23,24\end{array}$ & $\begin{array}{l}8 \\
8\end{array}$ \\
\hline & \multicolumn{2}{|c|}{ Jumlah } & 24 \\
\hline
\end{tabular}

Tabel

Kisi-kisi Instrumen Gaya Belajar

\begin{tabular}{|c|c|c|c|}
\hline Variabel & Indikator & Nomor Butir & Jumlah \\
\hline \multirow{4}{*}{$\begin{array}{l}\text { Gaya } \\
\text { belajar } \\
\text { siswa }\end{array}$} & 1. Visual & $1,2,3,4,5,6,7,8$ & 8 \\
\hline & 2. Auditorial & $8,9,10,11,12,13,14,15,16$ & 8 \\
\hline & 3. Kinestetik & $17,18,19,20,21,22,23,24$ & 8 \\
\hline & & & 24 \\
\hline
\end{tabular}




\section{HASIL DAN PEMBAHASAN}

Perhitungan statistik menggunakan analisis regresi dan korelasi sederhana dengan uji hipotesis yaitu uji t. Hasil perhitungan menunjukkan bahwa koefisien rhitung sebesar -0,08. Dengan demikian dapat disimpulkan bahwa antara pola asuh orang tua (X) dengan gaya belajar siswa (Y) tidak terdapat hubungan yang signifikan, karena nilai $\mathrm{r}$ kurang dari 0 dan bernilai negatif. Nilai koefisien determinasi (KD) sebesar 0,64\%, berarti kontribusi hubungan variable $\mathrm{X}$ (pola asuh orang tua) hanya sebesar 0,64\% saja, sisanya sebesar 99,36\% dipengaruhi oleh factor lain selain pola asuh orang tua. Persamaan regresi sederhana diperoleh $\mathrm{Y}=62,14-0,019 \mathrm{X}$ yang berarti jika ada kenaikan sebesar 1 skor pada variable $\mathrm{X}$ maka terdapat penurunan pada variable $\mathrm{Y}$ sebesar 0,09 dengan konstanta 62,14 atau dapat dikatakan juga terdapat kenaikan pada variable Y sebesar 62,05. Hasil uji hipotesis dengan t tabel pada $\mathrm{df}=30-2=28$ dengan taraf signifikasi 10\% didapat hasil 1,313. Sehingga hipotesis alternative (Ha) ditolak yaitu tidak terdapat hubungan yang signifikan antara variable $\mathrm{X}$ (pola asuh orang tua) dengan variable Y (gaya belajar siswa).

Menurut Rita Dunn (Sugihartono, 2007) pelopor di bidang gaya belajar yang lain telah menemukan banyak variable yang mempengaruhi gaya belajar siswa, diantaranya: fisik, emosional, sosiologis dan lingkungan. Salah satunya adalah lingkungan keluarga. Seseorang yang belajar akan menerima pengaruh dari keluarga berupa cara orang tua mendidik, relasi antar anggota keluarga, suasana rumah tangga dan keadaan ekonomi keluarga.

Berdasarkan teori tersebut menjelaskan bahwa factor lingkungan keluarga yaitu pola asuh memiliki hubungan yang signifikan dalam mempengaruhi gaya belajar siswa. Namun berdasarkan hasil penlitian lapangan yang kami lakukan bahwa gaya belajar siswa di SMA kharismawita tidak dipengaruhi dan tidak berhubungan dengan pola asuh oarng tua dirumahnya. Hal ini terlihat dari hasil uji korelasi sebesar - 0,08 dan hasil uji hipotesis sebesar -0,425. Adapun alasan ditolaknya Ha dan diterimanya Ho adalah karakteristik siswa di SMA kharismawita yang berusia remaja dimana pada usia ini anak sudah dapat menentukan pola belajar sesuai dengan karakteristik pribadinya tanpa pengaruh dari lingkungan di luar dirinya. Selain itu factor latar belakang orang tua yang berada di tengah kota besar yang memiliki kesibukan sehingga perhatian kepada anak yang berkurang. Faktor lain adalah kondisi siswa dalam menjawab angket 
yang kurang serius karena dianggap buka materi pelajaran yang penting.

Selain factor-faktor tersebut dapat disimpulkan bahwa masih terdapat factorfaktor lain yang memiliki hubungan dan pengaruh yang lebih besar dari factor pola asuh orang tua dalam mempengaruhi gaya belajar siswa SMA Kharismawita yaitu factor guru, perkembangan fisik dan emosional siswa, fasilitas sekolah, dan lain sebagainya.

\section{PENUTUP}

Simpulan

Berdasarkan hasil pengujian ternyata hipotesis yang diajukan ditolak. Pengujian hipotesis menyimpulkan bahwa tidak terdapat hubungan yang signifikan antara pola asuh oarng tua dengan gaya belajar siswa di SMA kharismawita Jakarta Selatan.

Saran

1. Perlu adanya perhatian dari pihak sekolah, orang tua dan masyarakat pada siswa untuk mengatasi masalah-masalah belajarnya selain gaya belajar.

2. Perlu adanya kajian yang lebih luas dan mendalam mengenai karakteristik siswa dan peran guru dalam mengatasi masalah belajar dengan dukungan orang tua.

\section{DAFTAR PUSTAKA}

Baykan, Z., \& Nacar, M. (2007). Learning Styles of First Year Medical. Student Attending Erciyes University in Kayscri, Turkey. Adv. Physiol Educ, 31,

Depdikbud. (2007). Kamus Besar Bahasa Indonesia. Jakarta: Balai Pustaka.

Deporter Bobbi dan Hernacki Mike (2011). Quantum Learning. Bandung: Kaifa.

Hurlock, Elizabeth B. (2002). Perkembangan Anak. Jakarta: Erlangga.

Nasution, S. (2011). Berbagai Pendekatan Dalam Proses Belajar dan Mengajar. Jakarta: Bumi aksara.

Papalia, Old, Feldman. (2008). Human Development (terjemahan). Jakarta: Kencana.

Santrock. John W. (2007). Perkembangan Anak/Child Development. Terj.Mila Rahmawati dan Anna Kuswanti. Jakarta : Erlangga. 
Sugihartono, dkk. 2007. Psikologi Pendidikan. Yogyakarta: UNY Press.

Slameto. 2003. Belajar dan Faktor-faktor yang Mempengaruhinya. Jakarta: Rineka Cipta.

Shochib, Moh., 2010. Pola Asuh Orang Tua (Dalam Membantu Mengembangkan Disiplin Diri Sebagai Pribadi Yang Berkarakter), Jakarta : Rineka Cipta.

TIM Penyusun Kamus Pusat Pembinaan dan Pengembangan Bahasa. (1988). Kamus Besar Bahasa Indonesia. Jakarta : Balai Pustaka.

Winkel, WS. (2009). Psikologi pengajaran. Yogyakarta: Media Abadi.

\section{Jurnal Online}

Bire, Arylien Ludji dan Josua Bire, 2015, Pengaruh Gaya Belajar Visual, Auditorial dan Kinestetik terhadap Prestasi Belajar Siswa. (Online). Volume 44. No. 2. http://journal.uny.ac.id/index.php/jk/article/view/5307 diunduh pada tanggal 17 Maret 2017 pukul 12.50 .

Fatmawati, Erni, 2015, Pengaruh Pola Asuh Orang Tua, Lingkungan, Gaya Belajar dan Motivasi terhadap Prestasi Belajar Mahasiswa. (Online).Volume 4. No 1. http://journal.ikippgriptk.ac.id/index.php/saintek/article/view/5 diunduh pada tanggal 17 Maret 2017 pukul 12.50.

Lestari, Nur Oktavianti, Saur M. Tampubolon, dan Yuyun Elizabeth Patras, 2015, Analisis Terhadap Pola Asuh Dan Gaya Belajar Siswa Berprestasi. (Online). Volume $7 . \quad$ No $\quad 2 . \quad$ http:// http://www.unpak.ac.id/uploads/dosen_8581_5_analisis_terhadap_pola_asuh_.p df diunduh pada tanggal 17 Maret 2017 pukul 12.50. 